Aleksandra MROCZEK-ŻULICKA

Uniwersytet Łódzki

\title{
WYCHOWAWCZA ROLA TURYSTYKI W DZIAŁANIACH POLSKICH ORGANIZACJI MEODZIEŻOWYCH
}

\section{Wprowadzenie}

Polskie organizacje młodzieżowe $\mathrm{w}$ swoich statutach często zamieszczają informacje o tym, że podejmują działania w zakresie turystyki. Nadrzędnym podmiotem ich oddziaływań jest człowiek - osoba młoda. Niezależnie od głównego celu tych organizacji, często to właśnie turystyka stanowi pole bądź narzędzie oddziaływań wychowawczych. Podejście to nie jest odkrywcze, wszak znaczenie turystyki w rozwoju człowieka jest niepodważalne. Interesującym natomiast aspektem jest forma, jaką przybiera ta aktywność $\mathrm{w}$ zakresie turystyki w organizacjach młodzieżowych, jej efekty czy też pogłębiona refleksja wychowawców - organizatorów działań.

Głównym celem opracowania jest opis przedsięwzięć turystycznych podejmowanych przez wybrane organizacje pod kątem ich roli wychowawczej. Autorka, dokonując analizy statutów stowarzyszeń i organizacji funkcjonujących w Polsce, przedstawia zapisy głównych celów oraz metod ich osiągnięcia, które nawiązują do działań w obrębie turystyki. Analiza ta pozwala na zaprezentowanie najczęściej wybieranych form aktywności w tym zakresie. Wskazuje także, dla jakich grup wiekowych są one przewidziane oraz jakie płaszczyzny kształtowania osobowości rozwijają. Kolejnym krokiem do pogłębienia analizy zakreślonej tematyki niniejszej pracy jest studium przypadków dotyczące form aktywności turystycznej wykorzystywanych w swo- 
jej działalności przez organizacje młodzieżowe. Określa też potencjał proponowanych rodzajów aktywności turystycznej pod kątem ich oddziaływania wychowawczego oraz pełnionej funkcji wychowawczej turystyki. Przypadki te analizowane są także $z$ perspektywy pedagogiki turystyki.

\section{Wychowawcza rola turystyki}

Złożony charakter przemian, które zachodzą za sprawą turystyki, dotyczy zarówno uczestników tego zjawiska, jak i miejsc, w jakich występują. Wynika to $\mathrm{z}$ faktu, że turystyka pojmowana jest jako wielowymiarowe zjawisko społeczno-gospodarcze i kulturowe (KUREK 2008). W efekcie zmiany te moga być analizowane w kategoriach ilościowych i jakościowych. Koncepcja funkcji turystyki wyrosła na gruncie badawczym o charakterze jakościowym. Charakteryzuje się opisywaniem przemian czy też korzyści - oczekiwanych oraz rzeczywistych - dla uczestników ruchu turystycznego oraz dla mieszkańców terenów odwiedzanych przez turystów. Na tej podstawie dokonywana jest ocena skutków rozwoju turystyki lub rozwoju uczestników tego procesu. Ocena ta ma charakter aksjologiczny, tzn. że określa pozytywne i negatywne cechy efektów tych oddziaływań (PRZECŁAWSKI 1973). Analiza funkcji turystyki rozpatrywana jest najczęściej w dwóch aspektach:

1) z punktu widzenia jednostki - turysty, oraz

2) w perspektywie konkretnej społeczności jako przedmiot badań socjologicznych i pedagogicznych. W dalszej części opracowania opisane będą tylko eufunkcje i dysfunkcje w odniesieniu do turystów.

Turystyka pełni różne funkcje, za podstawowe uznawane są: wypoczynkowa, zdrowotna, wychowawcza, ekonomiczna, kształceniowa, ochrony przyrody, polityczna, miastotwórcza i etniczna (KUREK 2008).

A. PANASIUK (2011), wskazując na złożoność zakresu i efektów rozwoju turystyki, wymienia trzy płaszczyzny, w których się kumulują jej funkcje: społeczno-kulturowa, gospodarcza oraz przestrzenno-środowiskowa. W.W. GAWORECKI (2010) wymienia zaś następujące funkcje turystyki: wypoczynkowa, zdrowotna, wychowawcza, kształceniowa, edukacji kulturowej, kształtowania świadomości ekologicznej, etniczna, ekonomiczna, miastotwórcza, polityczna oraz funkcja promocji wartości religijnych i kształtowania sprawiedliwości społecznej. Na podstawie tych klasyfikacji oraz obserwacji następstw masowości ruchu turystycznego, autorzy jednego z nowszych całościowych 
opracowań dotyczących turystyki (BALIŃSKA, SIECZKO, ZAWADKA 2014) proponują własny podział funkcji turystyki, wymieniając funkcje: wypoczynkowo-zdrowotną, poznawczo-kształceniową, wychowawczą, etniczną, ekonomiczną, polityczną i kształtowania przestrzeni.

Nie do przecenienia wydaje się wychowawcza funkcja turystyki obecna we wszystkich przytoczonych typologiach. Funkcja ta według W. KURKA (2008, s. 49) rozumiana jest: ,jako całokształt wpływów i oddziaływań na kształtowanie rozwoju człowieka (turysty) w trakcie wyjazdu turystycznego". M. BOCHENEK (2008) wskazuje na społeczno-wychowawcze wartości turystyki. Według tego autora wartości poznawcze i wychowawcze turystyki dotyczą: regeneracji zdrowia, podnoszenia poziomu kulturalnego, kształtowania postaw patriotycznych, zaspokajania potrzeb poznawczych, nawiązywania osobistych kontaktów, zaspokajania potrzeby wolności i nowości oraz zaspokajania potrzeby kształtowania postawy twórczej.

K. Przecławski, który jest uznawany za klasyka polskiej naukowej myśli pedagogicznej o turystyce (WINIARSKI 2008), szeroko opisał aspekt wychowania, kształtowania człowieka dzięki turystyce (PRZECŁAWSKI 1996). Według jego definicji wychowanie w tym zakresie musi być rozumiane szerzej, niż pojmują to przedstawiciele nauk pedagogicznych. Uważał bowiem, że to „całokształt oddziaływań społeczno-kulturowych, grupowych i jednostkowych, bezpośrednich i pośrednich, formalnych i nieformalnych, zamierzonych i niezamierzonych, powodujących względnie trwałą zmianę w osobowości jednostki w kierunku jej socjalizacji. Socjalizacja zaś to proces zmian zachodzących w jednostkach pod wpływem środowiska społeczno-kulturowego, polegający na rozwoju osobowości w kierunku społecznie pożądanym - nabywaniu umiejętności, przejmowaniu wartości norm i wzorów kulturowych, ich internacjonalizacji i organizowaniu w określony system wewnętrzny wyznaczający zachowanie człowieka" (PRZECŁAWSKI 1996, s. 96). W pedagogice zaś najczęściej przywoływana jest następująca definicja wychowania: „świadome i celowe działanie pedagogiczne zmierzające do osiągnięcia względnie stałych skutków (zmian rozwojowych) w osobowości wychowanka" (KWIECIŃSKI, ŚLIWERSKI 2011, s. 22).

Współcześnie, gdy rozwój turystyki staje się zjawiskiem coraz bardziej masowym, częściej doceniana jest jej rola wychowawcza. Sytuacja ta skłania ku refleksji nad możliwościami, jakie stwarza ona w wychowywaniu człowieka. Wszechstronne spektrum oddziaływań wiąże się z faktem, że dzięki turystyce można zaspokoić wiele podstawowych potrzeb człowieka, czy też wpływać na poprawę istotnych pól jego rozwoju. Pierwszym z nich jest 
rozwój fizyczny człowieka. Turystyka stwarza możliwości zapobiegania wielu chorobom (działanie profilaktyczne), dzięki niej bowiem można zregenerować własne siły - zarówno fizyczne, jak i psychiczne, wzmacniać zdrowie. Zatem zaspokaja potrzeby wypoczynku, a także ruchu i wysiłku fizycznego. Drugim polem oddziaływań jest rozwój psychospołeczny. Z jednej strony dzięki turystyce możemy zaspokoić potrzebę poznawczą, gdyż stwarza warunki do poznawania świata przyrodniczego, kulturowego oraz panujących stosunków międzyludzkich. Z drugiej strony pozwala też na realizację potrzeby osobistych kontaktów. Kolejną potrzebą w tej kategorii, realizowaną dzięki turystyce, jest potrzeba wolności. Turystyka umożliwia dokonywanie wyborów, gdyż daje poczucie niezależności i samostanowienia. Dzięki turystyce można także realizować potrzebę nowości - nabywania nowych doświadczeń i przeżyć. Niezwykle cenną rolą turystyki jest ponadto możliwość spełnienia potrzeby twórczości - twórczej pracy i działania. Tak zakrojone warunki oddziaływania wychowawczego stwarzają ogromne możliwości dla świadomych wychowawców czy organizatorów turystyki. K. PRZECŁAWSKI (1996) podkreśla, że niestety często nie są one w pełni wykorzystywane albo nie wszystkie i, co gorsze, niekiedy turystyka może pełnić funkcję antywychowawczą.

Wychowawcze funkcje turystyki mogą nieść zatem zarówno skutki pozytywne (eufunkcje), jak i negatywne (dysfunkcje). K. PRZECŁAWSKI (1996, s. 99-103) wymienia następujące eufunkcje w odniesieniu do turystów:

1) turystyka jako środek poznania rzeczywistości: bezpośredni, osobisty kontakt z przyrodą czy kulturą pozwala lepiej i silniej poznać otaczający świat; taka specyfika kontaktu ma niebagatelny wpływ na rozwój szczególnie dzieci i młodzieży;

2) dzięki turystyce kształtowane są określone postawy wobec rzeczywistości; poznawanie nowych osób - zarówno współtowarzyszy podróży, jak i mieszkańców odwiedzanych terenów - stwarza szanse kształtowania postaw altruistycznych, życzliwości, sympatii, a nawet przyjaźni. Zaspokajana jest także potrzeba osobistych kontaktów. W efekcie czego następuje proces integracji różnych grup społecznych, szczególnie w przypadku wyjazdów zagranicznych. W turystyce krajowej - krajoznawczej, można zaś mówić o kształtowaniu się świadomości narodowej. Ważnym aspektem jest także wspólnota przeżyć, która może skutkować budowaniem silnych więzi międzyludzkich, szczególnie w przypadku uprawiania turystyki kwalifikowanej. Taki aspekt procesu integracji może prowadzić zarówno do powstania bliskich relacji między grupami nieformalnymi (przyjaciele, rodzina), jak

\section{WARSZTATY Z GEOGRAFII TURYZMU}


i do powołania grup formalnych (kluby, stowarzyszenia, organizacje). Ponadto turystyka kształtuje postawę aktywną, uczy mierzyć się z wyzwaniami oraz minimalizować lęk, hartuje, dodaje odwagi i uczy wspólnoty w grupowym wysiłku. Dzięki temu można także mówić o kształtowaniu zdolności do adaptacji $\mathrm{w}$ nowych warunkach, odpowiedniego reagowania na zmiany i sytuacje stresujące. Turystyka z jednej strony może uczyć korzystania z postępu cywilizacji - np. szybkiego dostępu do wymarzonych miejsc podróży, a z drugiej strony pozwala dostrzec konieczność zatrzymania się, kontemplacji i refleksji nad nowo poznanym miejscem, pięknem przyrody czy dziełem ludzi;

3) turystyka jako środek kształtowania uczuć: dzięki podróżom kształtuje się emocjonalna warstwa ludzkiej psychiki; bliski kontakt z przyrodą, kulturą, ludźmi rozwijają ludzką emocjonalność, uczą i umożliwiają przeżywanie głębokich emocji;

4) turystyka jako pole możliwości działania twórczego: odnosi się zarówno do prac wykonanych na rzecz mieszkańców odwiedzanych terenów, jak i dzieł wytworzonych w trakcie własnych podróży; dzięki turystyce człowiek może oderwać się od rutynowych czynności i z nową energią wdrażać nowe pomysły;

5) turystyka jako „środek" na poprawę zdrowia; przebywanie na świeżym powietrzu, kontakt z przyrodą, możliwość ruchu, wysiłku fizycznego, złamanie codziennej rutyny - to wszystko służy utrzymaniu i potęgowaniu zdrowia;

6) turystyka jako czynnik resocjalizacji; wyjazd stwarza nowe możliwości wychowawcze, które są wykorzystywane zarówno przez rodziny, jak $\mathrm{i}$ instytucje resocjalizacyjne.

Dysfunkcje $\mathrm{w}$ odniesieniu do turystów dotyczą takich zjawisk, jak (PRZECŁAWSKI 1996, s. 105-108): powierzchowność poznania rzeczywistości, przeładowany program wycieczek, pogłębiająca się nieznajomość własnej kultury, postawa konsumpcyjna, niechęć wobec ludności odwiedzanych terenów, postawy lekceważenia norm współżycia społecznego, w tym postawy przestępcze, nadużywanie alkoholu, środków odurzających, nadmierna swoboda seksualna, dezintegracja $\mathrm{z}$ własnym środowiskiem, wzory wypoczynku biernego, niechęć powrotu do pracy po dłuższym wyjeździe.

Tak sformułowane negatywne funkcje turystyki pokazują wachlarz zagrożeń, jakie niesie nieodpowiednie przygotowanie, zaplanowanie i realizacja wyjazdu turystycznego. To bowiem czynniki determinujące wychowaw- 
cze efekty turystyki sprawiają, że powyższe funkcje mogą nieść pozytywne bądź negatywne skutki.

Siła oddziaływania wychowawczego zależy od grupy czynników związanych z turystą i z grupą czynników obiektywnych. Do pierwszej grupy należy przyporządkować rolę i pozycję społeczną turysty oraz jego doświadczenie turystyczne, które wpływają na osobowość, na już ukształtowane postawy człowieka. Najważniejszym czynnikiem determinującym wychowawczą funkcję turystyki jest zatem przede wszystkim człowiek - turysta. Dlatego istnieje pogląd, że większe szanse realnego wpływu na kształtowanie właściwych postaw jest możliwe w odniesieniu do dzieci i młodzieży, ze względu na fakt, że ich postawy nie są jeszcze w pełni ukształtowane. W drugiej grupie znajdą się natomiast wartości odwiedzanego środowiska (walory, ich dostępność, promocja), organizacja i warunki wyjazdu oraz osobowość organizatora, wychowawcy wyjazdu. A. DĄBROWSKI i K. PODLEŚNA-DUDICZ (2009) podkreślają znaczącą rolę wychowawcy, kierownika, instruktora wycieczki. Według nich osoba taka stanowi wzór dla uczestników, szczególnie dla dzieci i młodzieży. Może pozytywnie wpływać na rozbudzanie zainteresowań, skłaniać do pogłębiania umiejętności oraz ukierunkowywać i uczyć rozwijania aktywności i twórczej postawy. Warto dodać, że ważna jest także forma wyjazdu, która powinna sprzyjać indywidualnemu rozwojowi i pokonywaniu nowych wyzwań. Należy zatem zapewnić odpowiedni program wyjazdu, dobrze go zorganizować, zadbać o bezpieczeństwo oraz zapewnić wykwalifikowaną kadrę, która z rozmysłem wdroży zaplanowane cele.

\section{Obecność turystyki w statutach organizacji młodzieżowych}

Cele i zadania oraz strukturę organizacyjną stowarzyszeń młodzieżowych regulują ich statuty. Stanowią one podstawę prawną do określenia charakteru organizacji, ich głównych obszarów zainteresowań oraz zakresu działań. Zapisy statutowe stanowią zatem podstawę do wstępnej diagnozy wychowawczej roli turystyki w organizacjach młodzieżowych. Aby zapewnić różnorodność analizowanych organizacji, autorka wybrała te, które wchodzą w skład Polskiej Rady Organizacji Młodzieżowych (PROM). Ich misją jest: „Wzmacnianie głosu i potencjału młodych ludzi i organizacji młodzieżowych poprzez rzecznictwo ich interesów oraz wspieranie uczestnictwa młodzieży w życiu publicznym." (http://prom.info.pl). Członkowie zwyczajni 
Rady tworzą dwie izby: Izba Pierwsza składa się z organizacji młodzieżowych o zasięgu ogólnopolskim, zrzeszających powyżej 1 tys. członków, Izba Druga zrzesza pozostałe organizacje młodzieżowe. W Izbie Pierwszej znajduje się aktualnie sześć organizacji, zaś w Izbie Drugiej $21^{1}$.

Spośród 27 organizacji wchodzących w skład PROM autorce udało się dotrzeć do statutów 25. Wykluczono zatem z analizy dwie organizacje. Analiza treści statutów dotyczyła trzech aspektów:

1) czy cele organizacji związane są z szeroko pojętą turystyką?

2) czy sposoby i środki realizacji celów tych jednostek związane są z turystyką?

3) czy organizacje realizują inne formy działalności związane $z$ turystyką?

Należy zaznaczyć, że popularne obecnie wymiany międzynarodowe dzieci, młodzieży czy studentów również potraktowano jako formę aktywności turystycznej. Pozwoliło to zawęzić liczbę analizowanych organizacji, a także określić, dla których z nich działalność turystyczna jest celem czy środkiem działania umożliwiającym osiągnąć zamierzone rezultaty. W statutach sześciu z 25 organizacji nie znalazł się żaden zapis mówiący o działalności turystycznej, w związku z tym nie będą one w dalszej części opisywane (por. tab. 1).

Tab. 1. Zawartość statutów analizowanych organizacji młodzieżowych a turystyka

\begin{tabular}{|c|l|c|c|c|}
\hline Lp. & \multicolumn{1}{|c|}{ Nazwa organizacji } & $\begin{array}{c}\text { Cel } \\
\text { związany } \\
\text { z tury- } \\
\text { styką }\end{array}$ & $\begin{array}{c}\text { Realizacja } \\
\text { celów/metody } \\
\text { działania zwią- } \\
\text { zane z turystyką }\end{array}$ & $\begin{array}{c}\text { Inne działania } \\
\text { związane } \\
\text { z turystyką }\end{array}$ \\
\hline$[1]$ & \multicolumn{1}{|c|}{$[2]$} & {$[3]$} & {$[4]$} & {$[5]$} \\
\hline 1. & Akademicki Związek Sportowy & tak & tak & nie \\
\hline 2. & Stowarzyszenie Młodzi Demokraci & tak & tak & nie \\
\hline 3. & Zrzeszenie Studentów Polskich & tak & tak & tak \\
\hline 4. & Związek Harcerstwa Polskiego & nie & tak & nie \\
\hline 5. & Związek Harcerstwa Rzeczypospolitej & nie & tak & nie \\
\hline 6. & Związek Młodzieży Wiejskiej & tak & nie & nie \\
\hline 7. & AIESECa Polska & nie & tak & nie \\
\hline 8. & Centrum Inicjatyw Młodzieżowych & nie & tak & nie \\
\hline 9. & Centrum Inicjatyw UNESCO & nie & nie & \\
\hline
\end{tabular}

${ }^{1}$ Weryfikowano 15.02.2016. 


\begin{tabular}{|c|c|c|c|c|}
\hline [1] & [2] & [3] & [4] & [5] \\
\hline 10. & ESN - Erasmus Student Network & tak & tak & tak \\
\hline 11. & $\begin{array}{l}\text { Europejskie Forum Studentów AEGEE- } \\
\text { Kraków }\end{array}$ & nie & nie & nie \\
\hline 12. & $\begin{array}{l}\text { Międzynarodowe Stowarzyszenie } \\
\text { Studentów Medycyny IFMSA-Poland }\end{array}$ & nie & nie & nie \\
\hline 13. & Polska Młodzież Esperancka & nie & tak & tak \\
\hline 14. & $\begin{array}{l}\text { Polskie Stowarzyszenie Projektów } \\
\text { Młodzieżowych }\end{array}$ & tak & tak & tak \\
\hline 15. & $\begin{array}{l}\text { Stowarzyszenie Centrum Wolontariatu } \\
\text { w Kielcach }\end{array}$ & tak & tak & nie \\
\hline 16. & $\begin{array}{l}\text { Stowarzyszenie JES - Jakość Energia } \\
\text { Starachowice }\end{array}$ & tak & nie & nie \\
\hline 17. & Stowarzyszenie Projekt Polska & tak & nie & nie \\
\hline 18. & $\begin{array}{l}\text { Stowarzyszenie Przyjaciół Międzynarodo- } \\
\text { wego Ruchu ATD Czwarty Świat w Polsce }\end{array}$ & nie & nie & nie \\
\hline 19. & $\begin{array}{l}\text { Stowarzyszenie Przyjaciół Skwierzyń- } \\
\text { skiego Zespołu Tanecznego „Nowinka” }\end{array}$ & $\begin{array}{c}\text { brak } \\
\text { danych }\end{array}$ & $\begin{array}{c}\text { brak } \\
\text { danych }\end{array}$ & $\begin{array}{c}\text { brak } \\
\text { danych }\end{array}$ \\
\hline 20. & $\begin{array}{l}\text { Stowarzyszenie Rozwoju Integracji } \\
\text { Młodzieży }\end{array}$ & $\begin{array}{c}\text { brak } \\
\text { danych }\end{array}$ & $\begin{array}{c}\text { brak } \\
\text { danych }\end{array}$ & $\begin{array}{c}\text { brak } \\
\text { danych }\end{array}$ \\
\hline 21. & $\begin{array}{l}\text { Związek Młodzieży Mniejszości } \\
\text { Niemieckiej w RP }\end{array}$ & tak & nie & nie \\
\hline 22. & $\begin{array}{l}\text { Stowarzyszenia Jeleniogórskiej Młodzieży } \\
\text { All-ternatywa }\end{array}$ & tak & tak & nie \\
\hline 23. & Stowarzyszenia Elbląg Europa & tak & tak & nie \\
\hline 24. & Stowarzyszenie Europe4Youth & nie & nie & nie \\
\hline 25. & $\begin{array}{l}\text { Stowarzyszenia Podkarpackie Centrum } \\
\text { Edukacji Prawnej }\end{array}$ & nie & nie & nie \\
\hline 26. & Stowarzyszenia Projekt Tarnów & tak & tak & nie \\
\hline 27. & Stowarzyszenie Spektrum Możliwości & nie & tak & nie \\
\hline
\end{tabular}

a Dawna nazwa z języka francuskiego: Association Internationale des Étudiants en Sciences Économiques et Commerciales.

Źródło: opracowanie własne na podstawie źródeł internetowych.

W dziewięciu statutach z 25 analizowanych organizacji aktywność turystyczna jest zarówno celem, jak i metodą działania służącą osiąganiu zaplanowanych zamierzeń. Do tej grupy stowarzyszeń należą zaprezentowane w tab. 2.

Kolejną wyróżnioną grupą organizacji są te, których cele ogólne są związane $\mathrm{z}$ organizacją turystyki, ale metody działania, sposoby realizacji celów nie odnoszą się do tej dziedziny aktywności człowieka. Wyróżniono cztery takie organizacje z grupy 25 analizowanych. Są to: 
Tab. 2. Turystyka jako cel i metoda działania wybranych organizacji młodzieżowych

\begin{tabular}{|c|c|c|c|}
\hline Lp. & $\begin{array}{c}\text { Nazwa } \\
\text { organizacji }\end{array}$ & $\begin{array}{l}\text { Cel/charakter } \\
\text { organizacji }\end{array}$ & $\begin{array}{c}\text { Działanie } \\
\text { na rzecz turystyki }\end{array}$ \\
\hline [1] & [2] & [3] & [4] \\
\hline 1. & $\begin{array}{l}\text { Akademicki } \\
\text { Związek } \\
\text { Sportowy }\end{array}$ & $\begin{array}{l}\text { „Studencka organizacja sportu } \\
\text { akademickiego o zasięgu ogól- } \\
\text { nokrajowym, reprezentująca } \\
\text { swoich członków w sprawach } \\
\text { związanych z upowszechnia- } \\
\text { niem i rozwojem kultury fi- } \\
\text { zycznej w środowisku akade- } \\
\text { mickim”a. }\end{array}$ & $\begin{array}{l}\text { „Upowszechnianie kultury fizycznej i tury- } \\
\text { styki, podnoszenie sprawności fizycznej } \\
\text { i polepszanie stanu zdrowia społeczności } \\
\text { akademickiej”. Organizacja realizuje swoje } \\
\text { cele m.in. przez „,organizowanie życia spor- } \\
\text { towego, rekreacji i turystyki [...], organizo- } \\
\text { wanie obozów sportowych, adaptacyjnych, } \\
\text { integracyjnych, szkoleniowych, rekreacyj- } \\
\text { nych i turystycznych [...], propagowanie } \\
\text { różnych form sportu, rekreacji i turystyki”. }\end{array}$ \\
\hline 2. & $\begin{array}{l}\text { Stowarzyszenie } \\
\text { Młodzi } \\
\text { Demokraci }\end{array}$ & $\begin{array}{l}\text { Stowarzyszenie zrzesza mło- } \\
\text { dych ludzi, którym zależy na } \\
\text { uczestnictwie „w budowie } \\
\text { Polski nowoczesnej, wolnej, } \\
\text { silnej, zajmującej godne miejsce } \\
\text { w Europie i świecie”b. }\end{array}$ & $\begin{array}{l}\text { „Promocja kultury fizycznej, sportu i tury- } \\
\text { styki”, a jednym ze sposobów realizacji } \\
\text { celów jest organizacja „wymiany między- } \\
\text { narodowej ludzi młodych”. }\end{array}$ \\
\hline 3. & $\begin{array}{l}\text { Zrzeszenie } \\
\text { Studentów } \\
\text { Polskich }\end{array}$ & $\begin{array}{l}\text { Organizacja, której głównym } \\
\text { celem jest wspieranie i pomoc } \\
\text { dla środowiska akademickiego. }\end{array}$ & $\begin{array}{l}\text { „Organizowanie działalności turystycznej, } \\
\text { rozwijanie turystyki kwalifikowanej oraz } \\
\text { propagowanie różnorodnych form aktyw- } \\
\text { nego wypoczynku”c. Wymieniane zaś for- } \\
\text { my działania to m.in.: obozy młodzieżowe } \\
\text { i studenckie, imprezy turystyczne i sporto- } \\
\text { we, a także wymiany międzynarodowe. }\end{array}$ \\
\hline 4. & $\begin{array}{l}\text { ESN - Erasmus } \\
\text { Student } \\
\text { Network }\end{array}$ & $\begin{array}{l}\text { Organizacja zajmująca się pro- } \\
\text { mocją i organizacją między- } \\
\text { narodowych wymian stu- } \\
\text { denckich. }\end{array}$ & $\begin{array}{l}\text { „Wspomaganie międzynarodowych eduka- } \\
\text { cyjnych i kulturalnych wymian studenckich } \\
{[\ldots], \text { krajoznawstwo oraz wypoczynek mło- }} \\
\text { dzieży i studentów”d.Organizacja realizuje } \\
\text { swoje cele poprzez m.in.: organizację wy- } \\
\text { mian studenckich i młodzieżowych. }\end{array}$ \\
\hline 5. & $\begin{array}{l}\text { Polskie } \\
\text { Stowarzyszenie } \\
\text { Projektów } \\
\text { Młodzieżowych }\end{array}$ & $\begin{array}{l}\text { Działalność międzynarodowa, } \\
\text { wspólnoty lokalne, aktywność } \\
\text { społeczna. Działalność na rzecz } \\
\text { integracji europejskiej oraz roz- } \\
\text { wijania kontaktów i współpra- } \\
\text { cy między społeczeństwami. }\end{array}$ & $\begin{array}{l}\text { „Wspieranie wypoczynku dzieci i młodzie- } \\
\text { ży, działalność w zakresie kultury fizycznej } \\
\text { oraz sportu, wspieranie turystyki i krajo- } \\
\text { znawstwa”e. Stowarzyszenie to realizuje } \\
\text { swoje cele poprzez: m.in.: „organizowanie } \\
\text { imprez kulturalnych, turystycznych i spor- } \\
\text { towych.” Ponadto stowarzyszenie to może } \\
\text { prowadzić działalność gospodarczą, we- } \\
\text { dług własnego statutu, m.in. w następują- } \\
\text { cym zakresie: działalność organizatorów } \\
\text { turystyki, działalność turystyczna pozostała. }\end{array}$ \\
\hline
\end{tabular}




\begin{tabular}{|c|c|c|c|}
\hline [1] & [2] & [3] & [4] \\
\hline 6. & $\begin{array}{l}\text { Stowarzyszenie } \\
\text { Centrum } \\
\text { Wolontariatu } \\
\text { w Kielcach }\end{array}$ & $\begin{array}{l}\text { Jest to stowarzyszenie pośred- } \\
\text { niczące między organizacjami } \\
\text { potrzebującymi wsparcia wo- } \\
\text { lontariuszy a osobami, które tej } \\
\text { pomocy pragną udzielić. }\end{array}$ & $\begin{array}{l}\text { Cele, jak i sposoby działania, w tym: „dzia- } \\
\text { łalność na rzecz wypoczynku dzieci i mło- } \\
\text { dzieży”f. }\end{array}$ \\
\hline 7. & $\begin{array}{l}\text { Stowarzyszenia } \\
\text { Jeleniogórskiej } \\
\text { Młodzieży All- } \\
\text { ternatywa }\end{array}$ & $\begin{array}{l}\text { Kierunki działalności: „Aktyw- } \\
\text { ne uczestnictwo młodych w de- } \\
\text { cyzjach i przedsięwzięciach na } \\
\text { szczeblu lokalnym i regio- } \\
\text { nalnym"g. }\end{array}$ & $\begin{array}{l}\text { „Popularyzowanie rekreacji i turystyki jako } \\
\text { form aktywnego stylu życia." Stowarzy- } \\
\text { szenie realizuje swoje cele m.in. poprzez: } \\
\text { "prowadzenie wymian oraz projektów } \\
\text { międzynarodowych". }\end{array}$ \\
\hline 8. & $\begin{array}{l}\text { Stowarzyszenia } \\
\text { Elbląg Europa }\end{array}$ & $\begin{array}{l}\text { Misją stowarzyszenia jest } \\
\text { „realizowanie i popieranie } \\
\text { wszelkich działań służących } \\
\text { dobru mieszkańców Elbląga } \\
\text { i regionu elbląskiego"h. }\end{array}$ & $\begin{array}{l}\text { „Promocja rekreacji, turystyki, sportu i kul- } \\
\text { tury fizycznej”. Stowarzyszenie realizuje } \\
\text { swoje cele poprzez m.in.: „Organizowanie } \\
\text { spotkań, szkoleń, seminariów, wystaw, od- } \\
\text { czytów, dyskusji, konkursów, koncertów, } \\
\text { obozów, rajdów, imprez, pokazów oraz } \\
\text { innych [...]. Organizację współpracy i wy- } \\
\text { miany międzynarodowej, wizyt studyj- } \\
\text { nych, staży, wycieczek, obozów i kursów } \\
\text { językowych”. }\end{array}$ \\
\hline 9. & $\begin{array}{l}\text { Stowarzyszenia } \\
\text { Projekt Tarnów }\end{array}$ & $\begin{array}{l}\text { Stowarzyszenie zrzesza mło- } \\
\text { dych liderów w celu włączenia } \\
\text { ich w aktywne działanie spo- } \\
\text { łeczno-polityczne. }\end{array}$ & $\begin{array}{l}\text { „Prowadzenie działalności w zakresie [...] } \\
\text { sportu, turystyki i rekreacji”i. Stowarzy- } \\
\text { szenie realizuje swoje cele m.in. przez: } \\
\text { „organizowanie, udział, finansowanie: } \\
\text { spotkań, zebrań, zjazdów, sympozjów, } \\
\text { konferencji, prelekcji, pogadanek, dyskusji, } \\
\text { kursów, szkoleń, zlotów, obozów, rozgry- } \\
\text { wek i zawodów sportowych, koncertów, } \\
\text { konkursów, przeglądów”. }\end{array}$ \\
\hline
\end{tabular}

a http://azs.pl/.

b http://www.smd.org.pl/.

${ }^{c}$ http://zsp.pl/.

d http://esn.pl/.

e http://www.eyca.pl/pl/.

${ }^{\mathrm{f}} \mathrm{http}: / /$ centrumwolontariatu.eu/.

g http://docplayer.pl/.

h Statut Stowarzyszenia Elbląg Europa, Elbląg 2011 (dostęp do dokumentu autorka otrzymała drogą elektroniczną).

${ }^{i}$ http:// projekttarnow.org/.

Źródło: opracowanie własne na podstawie źródeł internetowych. 
Tab. 3. Turystyka jako cel działania wybranych organizacji młodzieżowych

\begin{tabular}{|c|c|c|c|}
\hline Lp. & $\begin{array}{c}\text { Nazwa } \\
\text { organizacji }\end{array}$ & $\begin{array}{l}\text { Cel/charakter } \\
\text { organizacji }\end{array}$ & $\begin{array}{c}\text { Działanie } \\
\text { na rzecz turystyki }\end{array}$ \\
\hline 1. & $\begin{array}{l}\text { Związek } \\
\text { Młodzieży } \\
\text { Wiejskiej }\end{array}$ & $\begin{array}{l}\text { Reprezentowanie interesów } \\
\text { młodzieży z obszarów wiejskich } \\
\text { i małych miasteczek. }\end{array}$ & $\begin{array}{l}\text { „Organizacja wypoczynku dla dzieci } \\
\text { i młodzieży, [...] działalność w sferze } \\
\text { kultury fizycznej, [...] w tym wychowania } \\
\text { fizycznego, rekreacji i sportu, [...] pro- } \\
\text { mocja turystyki i krajoznawstwa, w tym } \\
\text { agroturystyki i turystyki wiejskiej”a. } \\
\text { Ponadto stowarzyszenie prowadzi dzia- } \\
\text { łalność gospodarczą m.in. w zakresie: } \\
\text { działalności pośredników turystycznych, } \\
\text { działalności organizatorów turystyki, } \\
\text { obiektów noclegowych turystycznych } \\
\text { i miejsc krótkotrwałego zakwaterowania }\end{array}$ \\
\hline 2. & $\begin{array}{l}\text { Stowarzyszenie } \\
\text { JES - Jakość } \\
\text { Energia } \\
\text { Starachowice }\end{array}$ & $\begin{array}{l}\text { „Wyzwalanie energii Staracho- } \\
\text { wiczan do aktywności obywa- } \\
\text { telskiej”b. }\end{array}$ & $\begin{array}{l}\text { „Tworzenie wirtualnej platformy informa- } \\
\text { cyjnej skupiającej mieszkańców, turystów, } \\
\text { inwestorów i sympatyków Starachowic } \\
\text { [...] działalność z dziećmi i z młodzieżą } \\
\text { oraz na rzecz dzieci i młodzieży"c. }\end{array}$ \\
\hline 3. & $\begin{array}{l}\text { Stowarzyszenie } \\
\text { Projekt Polska }\end{array}$ & $\begin{array}{l}\text { „Powołujemy Stowarzyszenie } \\
\text { Projekt: Polska, organizację no- } \\
\text { wego pokolenia, które chce od- } \\
\text { ważnie budować otwartą i no- } \\
\text { woczesną Polskę”d. }\end{array}$ & $\begin{array}{l}\text { „Promocja kultury fizycznej, sportu i tu- } \\
\text { rystyki". }\end{array}$ \\
\hline 4. & $\begin{array}{l}\text { Związek Mło- } \\
\text { dzieży Mniej- } \\
\text { szości Niemiec- } \\
\text { kiej w RP }\end{array}$ & $\begin{array}{l}\text { Organizacja zrzeszająca młodych } \\
\text { ludzi, którzy pragną poprzez za- } \\
\text { bawę i edukację kształtować toż- } \\
\text { samość niemiecką oraz rozwijać } \\
\text { współpracę polsko-niemiecką. }\end{array}$ & $\begin{array}{l}\text { „Organizowanie wypoczynku dzieci } \\
\text { i młodzieży, turystyki i krajoznawstwa”e. }\end{array}$ \\
\hline
\end{tabular}

a http://www.zmw.pl/.

b http://jes.org.pl/.

c http://jes.org.pl/.

d http://projektpolska.pl/.

e http:/ / www.bjdm.eu/.

Źródło: opracowanie własne na podstawie źródeł internetowych.

Do ostatniej wydzielonej grupy organizacji młodzieżowych należą takie, których cele, mimo że niezwiązane $\mathrm{z}$ obszarem turystyki, realizowane są poprzez działania turystyczne. Spośród 25 analizowanych stowarzyszeń wyodrębniono sześć takich organizacji, których cele i działania zaprezentowano w tab. 4. 
Tab. 4. Turystyka jako metoda realizacji celów wybranych organizacji młodzieżowych

\begin{tabular}{|c|c|c|c|}
\hline Lp. & $\begin{array}{l}\text { Nazwa } \\
\text { organizacji }\end{array}$ & $\begin{array}{l}\text { Cel/charakter } \\
\text { organizacji }\end{array}$ & $\begin{array}{l}\text { Działanie } \\
\text { na rzecz turystyki }\end{array}$ \\
\hline [1] & [2] & [3] & {$[4]$} \\
\hline 1. & $\begin{array}{l}\text { Związek } \\
\text { Harcerstwa } \\
\text { Polskiego }\end{array}$ & $\begin{array}{l}\text { Stwarzanie warunków do } \\
\text { wszechstronnego, intelektualnego, } \\
\text { społecznego, duchowego, } \\
\text { emocjonalnego i fizycznego rozwoju } \\
\text { człowieka. }\end{array}$ & $\begin{array}{l}\text { „ZHP organizuje przedsięwzięcia } \\
\text { związane z rozwojem zainteresowań } \\
\text { i specjalności w zakresie kultury fi- } \\
\text { zycznej i sportu oraz turystyki i kra- } \\
\text { joznawstwa, organizuje letni i zimo- } \\
\text { wy wypoczynek w formach wyjaz- } \\
\text { dowych i w miejscu zamiesz- } \\
\text { kania”a. }\end{array}$ \\
\hline 2. & \begin{tabular}{|l} 
Związek \\
Harcerstwa \\
Rzeczypospolitej
\end{tabular} & $\begin{array}{l}\text { „Wychowanie człowieka metodą } \\
\text { harcerską: w myśl Przyrzeczenia } \\
\text { i Prawa Harcerskiego, do świado- } \\
\text { mej postawy obywatelskiej w po- } \\
\text { czuciu współodpowiedzialności za } \\
\text { losy własnej rodziny, narodu i pań- } \\
\text { stwa polskiego, upowszechnianie } \\
\text { w społeczeństwie ideałów harcer- } \\
\text { skich }{ }^{b} \text {. }\end{array}$ & $\begin{array}{l}\text { ZHR realizuje swoje cele m.in. po- } \\
\text { przez: „turystykę, krajoznawstwo } \\
\text { oraz organizację wypoczynku dzieci } \\
\text { i młodzieży”. }\end{array}$ \\
\hline 3. & AIESEC & $\begin{array}{l}\text { "Głównym założeniem jest zwięk- } \\
\text { szanie zrozumienia kulturowego } \\
\text { i współpracy międzynarodowej po- } \\
\text { przez program wymiany praktyk"c. }\end{array}$ & $\begin{array}{l}\text { „Program Międzynarodowej Wymia- } \\
\text { ny Praktyk jest główną formą realiza- } \\
\text { cji celów tejże organizacji”d. }\end{array}$ \\
\hline 4. & $\begin{array}{l}\text { Centrum } \\
\text { Inicjatyw } \\
\text { Młodzieżowych } \\
\text { „Horyzonty” }\end{array}$ & $\begin{array}{l}\text { Organizacja zrzesza młodych, ak- } \\
\text { tywnych ludzi, którzy działają na } \\
\text { rzecz rozwijania międzynarodowej } \\
\text { i międzykulturowej współpracy } \\
\text { młodzieży. }\end{array}$ & $\begin{array}{l}\text { Swoje cele statutowe realizuje m.in. } \\
\text { poprzez wymiany młodzieży"e. }\end{array}$ \\
\hline 5. & $\begin{array}{l}\text { Polska Młodzież } \\
\text { Esperancka }\end{array}$ & $\begin{array}{l}\text { PME jest sekcją Polskiego Związku } \\
\text { Esperantystów, którego celem jest: } \\
\text { rozpowszechnianie i nauczanie } \\
\text { języka esperanto. }\end{array}$ & $\begin{array}{l}\text { Cele realizowane są m.in. poprzez: } \\
\text { „prowadzenie ośrodków [...], tury- } \\
\text { stycznych oraz szkoleniowych, [...] } \\
\text { organizowanie różnych form turysty- } \\
\text { ki i wypoczynku połączonych z prak- } \\
\text { tycznym zastosowaniem języka espe- } \\
\text { ranto, [...] promocję walorów tury- } \\
\text { stycznych i bogactwa kulturowego } \\
\text { kraju poprzez wydawnictwa na ten } \\
\text { temat w języku esperanto, [...] inte- } \\
\text { grację międzypokoleniową, realizo- } \\
\text { waną we wspólnych przedsięwzię- } \\
\text { ciach edukacyjnych, kulturalnych i tu- } \\
\text { rystycznych }{ }^{\prime \prime} \text {. Ponadto PZE „,reali- }\end{array}$ \\
\hline
\end{tabular}




\begin{tabular}{|c|l|l|l|}
\hline$[1]$ & \multicolumn{1}{|c|}{$[2]$} & \multicolumn{1}{|c|}{$[3]$} & \multicolumn{1}{c|}{$[4]$} \\
\hline cd. & $\begin{array}{l}\text { Polska Młodzież } \\
\text { Esperancka }\end{array}$ & $\begin{array}{l}\text { zuje swoje cele zgodnie z obowiązują- } \\
\text { cymi przepisami poprzez: [...] powo- } \\
\text { fywanie i rozwiązywanie jednostek } \\
\text { gospodarczych i ośrodków [...] tury- } \\
\text { stycznych oraz szkoleniowych dla } \\
\text { potrzeb PZE”. }\end{array}$ \\
\hline 6. & $\begin{array}{l}\text { Stowarzyszenie } \\
\text { Spektrum } \\
\text { Możliwości }\end{array}$ & $\begin{array}{l}\text { "Wspieranie aktywności mieszkań- } \\
\text { ców województwa świętokrzys- } \\
\text { kiego poprzez organizowanie róż- } \\
\text { norodnych przedsięwzięć, w szcze- } \\
\text { gólności skierowanych do dzieci } \\
\text { i młodzieży." }\end{array}$ & $\begin{array}{l}\text { Stowarzyszenie realizuje swoje cele } \\
\text { m.in. dzięki: ,organizowaniu imprez } \\
\text { kulturalnych, artystycznych i rekrea- } \\
\text { cyjno-sportowych, oraz wyjazdów } \\
\text { turystycznych, promocji krajoznaw- } \\
\text { stwa poprzez turystykę wśród dzieci } \\
\text { i młodzieży, w szczególności w ra- } \\
\text { mach letniego i zimowego wypo- } \\
\text { czynku." }\end{array}$ \\
\hline
\end{tabular}

a http://dokumenty.zhp.pl/.

b https:/ / www.zhr.pl.

${ }^{c}$ http://aiesec.pl/.

d https:/ / drive.google.com.

e http://www.cimhoryzonty.org/.

${ }^{\mathrm{f}}$ http:/ / spektrummozliwosci.pl/.

g Statut Stowarzyszenia „Spektrum Możliwości”, Miedziana Góra 2011 (dostęp do dokumentu autorka otrzymała drogą elektroniczną).

Źródło: opracowanie własne na podstawie źródeł internetowych.

Na 25 analizowanych statutów organizacji młodzieżowych w 19 znalazły się zapisy na temat działalności w zakresie turystyki. Najczęściej przywoływane cele obejmujące turystykę dotyczyły promocji lub jej upowszechniania oraz organizacji wypoczynku dzieci i młodzieży. Zapisy te ukazywały chęć popularyzacji aktywnych form wypoczynku, zachęcanie do rekreacji i krajoznawstwa. Organizowanie wyjazdów turystycznych dla dzieci i młodzieży jest niezwykle popularną formą aktywności tego typu stowarzyszeń i często stanowi również środek do osiągnięcia celów zapisanych w statucie. Są to bardzo zróżnicowane formy turystyki, rekreacji i sportu. Najczęściej wspominane były wymiany oraz wypoczynek letni i zimowy. Działania te prowadzone są dla wszystkich grup wiekowych dzieci i młodzieży oraz studentów. Opisywane organizacje rzadko prowadzą działalność gospodarczą w zakresie turystyki.

Znacząca obecność zapisów statutowych odwołujących się do aktywności w obrębie turystyki uwypukla różnorodną rolę turystyki w działaniach 
polskich organizacji młodzieżowych. Może to także potwierdzać tezę o ogromnym potencjale turystyki, możliwościach, jakie ona daje. Płaszczyzna oddziaływań kształtowanych przez turystykę jest bardzo szeroka. Odwołując się do przywołanych zapisów statutowych można stwierdzić, że opisywane organizacje młodzieżowe w dużym stopniu wpływają na kształtowanie postaw wobec turystyki, uczą wzorów wypoczynku. Nie sposób jest jednak dokonać analizy wszelkich form, jakie może przybierać, oraz wpływu, jaki niesie ze sobą. Autorka pozostawia to pole jako punkt wyjścia do kolejnych badań i analiz.

\section{Przedsięwzięcia turystyczne wybranych organizacji młodzieżowych - analiza przypadków i ich krytyka}

W celu zaprezentowania wykorzystania potencjału wychowawczego w turystyce dokonano analizy trzech przypadków różnych form wyjazdów dzieci i młodzieży na wypoczynek. Głównym celem tej jakościowej metody badań jest opis, często dotyczący jednorazowego, jedynego w swoim rodzaju badanego zjawiska (BABBIE 2003). Przeprowadzone studia mają na celu szczegółowe opisanie struktury wybranych przypadków obozów młodzieżowych (sytuacji "turystycznych") jako sytuacji wychowawczych. Taka struktura obejmuje: 1) sferę przedmiotową oddziaływań wychowawczych, czyli wszystko to, co oddziałuje na turystę (ludzi, przyrodę, kulturę, przestrzenie); 2) sferę podmiotową, tj. poszukującego i odbierającego turystę, oraz 3) sferę podmiotowo-przedmiotową, a więc stan zmiany - odmienności od codzienności, która może wpływać na podmiot (WINIARSKI 2008). Przegląd studiów przypadków oparto także na wiedzy z zakresu wychowawczej roli turystyki: form oddziaływania wychowawczego i funkcji wychowawczej turystyki. Na podstawie zebranych od organizacji i stowarzyszeń oraz wyszukanych za pośrednictwem Internetu informacji dotyczących programów obozów czy innych imprez turystycznych organizowanych przez nie, autorka wybrała trzy najbardziej popularne wśród nich formy wyjazdów: obozy sportowe, integracyjne obozy studenckie oraz obozy młodzieżowe organizacji wychowawczych. Wybór ten - dość subiektywny - podyktowany był chęcią zobrazowania różnorodnych, czasem nawet skrajnych możliwości oraz skutków wychowawczych, jakie daje organizacja wyjazdów dla dzieci i młodzieży. 


\subsection{Obozy sportowe}

Szczególnym rodzajem wyjazdów wypoczynkowych skierowanych do młodzieży są obozy sportowe. Skupione są przede wszystkim na intensywnym realizowaniu programu sportowego z wybranej, zazwyczaj jednej dyscypliny. Oddział AZS Uniwersytetu Warszawskiego zaplanował na okres 15-22 sierpnia 2016 roku obóz tenisowy w ośrodku AZS w Wilkasach, który położony jest nad jeziorem Niegocin na Mazurach. Program obozu przewidywał przede wszystkim grę $\mathrm{w}$ tenisa, $\mathrm{w}$ tym kurs zarówno dla początkujących, jak i dla zaawansowanych zakończony uczestnictwem $w$ turnieju tenisowym. Poza zajęciami ",tenisowymi”, trwającymi 3 godziny dziennie, zaplanowano także zajęcia dodatkowe $\mathrm{w}$ postaci rekreacji na plaży, na boisku oraz korzystanie $\mathrm{z}$ siłowni. W ulotce promocyjnej zawarto także informację o przewidzianym w ramach turnusu ognisku i rejsie kajakowym. Organizatorzy zapewnili wykwalifikowaną i doświadczoną kadrę (http://www. kuazsuw.pl/).

Częstochowski oddział AZS organizuje cykliczne obozy sportowe - siatkarskie pod nazwą: Professional Volley Camp dla dziewcząt i chłopców w wieku 10-17 lat. W 2016 roku przewidziano organizację czterech turnusów, w zależności od terminu, na 8 do 11 dni każdy. Organizatorzy zapraszają do Częstochowy - stolicy polskiej siatkówki i kuźni siatkarskich talentów. Ambasadorem obozu został Mistrz Świata i Mistrz Olimpijski Ryszard Bosek, co podnosi prestiż imprezy. Ponadto jako kadra trenerska w edycji 2016 roku zaproszeni zostali: Damian Dacewicz, Michał Bąkiewicz i Wojciech Pudo. Program obozu przewiduje następujące zajęcia: dwa treningi po około 2 godziny dziennie (treningi, rozwijanie techniki oraz zapoznanie $\mathrm{z}$ regułami gry i zasadami sędziowania meczy), zajęcia ogólnosportowe rozwijające: skoczność, gibkość i wytrzymałość. Dodatkowo zaplanowano dla uczestników wyprawę Szlakiem Orlich Gniazd oraz zwiedzanie Klasztoru na Jasnej Górze (http://www.volleycamp.pl/). Obozy te cieszą się bardzo dobrą opinią, uczestnicy wyjazdów oraz ich rodzice podkreślają wysoką jakość prowadzonych treningów, dobrą organizację i profesjonalizm szkoleniowców (http://www.volleycamp.pl/).

Przedstawione studia przypadków obrazują obozy sportowe jako imprezy szczególnie nastawione na rozwój fizyczny uczestników. Program zapewnia bogaty plan zajęć związanych z wybraną dyscypliną sportową, ale także zajęcia ogólnorozwojowe czy rekreację ruchową. Zdecydowanie mniejszy nacisk położony jest na rozwój psychospołeczny. Nie jest on na pewno celem 
nadrzędnym tych wydarzeń, jednak tak intensywne zajęcia sportowe w grupie rówieśniczej (szczególnie gra zespołowa, jaką jest siatkówka) sprzyjają rozwijaniu relacji międzyludzkich oraz realizowaniu potrzeby osobistych kontaktów. Zdecydowanie w mniejszym stopniu realizowana jest potrzeba wolności - swobodnego wyboru własnej aktywności lub potrzeba nowości. Element krajoznawczy - poznawania otoczenia, jest realizowany marginalnie. Przedstawione obozy sportowe nie obejmują w swym programie działań rozwijających potrzebę twórczości.

Skutki wychowawcze tak realizowanej formy wyjazdu turystycznego w małym stopniu sprzyjają poznawaniu rzeczywistości; działanie to nie jest priorytetowe, w przeciwieństwie do działań skierowanych na rzecz poprawy zdrowia i sprawności fizycznej. Interesującym zagadnieniem jest w przekonaniu autorki potencjał rozwijania postaw za pomocą obozów sportowych. Wyjazdy tego typu mogą stać się sposobnością kształtowania otwartości, tolerancji i integracji uczestników, a przede wszystkim jest to miejsce, w którym jest możliwość budowania silnych więzi opartych na wspólnych przeżyciach (np. długie i obciążające treningi). Z kolei zagrożeniem wychowawczym wynikającym z tego typu wyjazdów może być jego powierzchowność w poznaniu rzeczywistości, a przeładowany zajęciami sportowymi program może zniechęcać do poznawania okolicznego terenu, jego historii, przyrody i kultury. Skutkować to może pogłębianiem nieznajomości kultury narodowej przez uczestników takich obozów.

\subsection{Obozy studenckie}

Studenckie obozy integracyjne zazwyczaj są organizowane dla studentów pierwszego roku w celu budowania relacji, ale także zabawy. Wiele polskich uczelni, w których funkcjonują organizacje studenckie proponują taką formę zakończenia wakacji, relaksu po maturze i przygotowania się do życia studenckiego.

Zrzeszenie Studentów Polskich działające przy Szkole Głównej Handlowej w Warszawie organizuje cyklicznie wyjazd integracyjny "Zerówka - Czarniecka". W 2015 roku wyjazd tego typu trwał od 1 do 8.09.2015 roku i odbywał się w Mrozach koło Ełku. Program wyjazdu zapewniał organizację kilku imprez tematycznych (np. „Hawaii Party”, „Pimps \& Bitches”), kulinarnych (pieczenie barana), konkursy z nagrodami, grę miejską „Treasure Hunting", paintball, różne formy rekreacji ruchowej. Organizatorzy zapewniali, że będzie to okazja do świetnej zabawy, poznania ludzi i dowie- 
dzenia się najważniejszych rzeczy o studiowaniu na SGH (http://www. zerujemyrazem.pl/).

Również przy SGH działa organizacja studencka ESN, która organizuje "zerówkowy” obóz dla studentów. W 2015 roku odbyły się dwa turnusy we Władysławowie $\mathrm{w}$ następujących terminach: 24.08-01.09.2015 roku oraz 31.08-08.09.2015. Siedmiodniowy turnus zapewniał następujący program: spływ kajakowy na terenie Kaszub, oglądanie elektrowni wodnej w Żarnowcu, grę terenową "Treasure Hunting", rekreację ruchową (park linowy, paintball, aquapark), tematyczne imprezy („Las Vegas Party”, "Aloha Hawaii Party”, ,"College Party”, ,"Viking Night”, ,Farewell Party”). Organizatorzy zachęcali również w programie do plażowania i kąpieli w morzu oraz do korzystania z atrakcji turystycznych Władysławowa (http:/ / aiyd.eu/).

Trzeci przypadek obozu integracyjnego to "Adapciak", organizowany przez AIESEC i także skierowany do studentów SGH. Organizatorzy tego wyjazdu zapewniali, że jest on okazją do zawarcia nowych znajomości i zapoznania się z funkcjonowaniem uczelni, a także najlepszą formą zakończenia wakacji. Program wyjazdu zawiera imprezy tematyczne, symulacje dnia na uczelni, gry terenowe i strategiczne, spotkanie kulturowe "Global Village", rekreację ruchową (kajaki), plażowanie i kąpiel w jeziorze. Ponadto organizatorzy zapewnili udział w szkoleniach z zakresu „umiejętności miękkich" oraz w sesjach rozwijających kreatywność i przedsiębiorczość. Warto dodać, że w obozie uczestniczą też zagraniczni wolontariusze, dzięki czemu uczestnicy mają szansę poznać inne kultury i rozwijać swoje umiejętności językowe. W 2015 roku obóz zorganizowany był w Ośrodku ,Jakub” w Kruklankach na Mazurach w terminie 31.08.-06.09.2015 (https://www.face book.com/).

Specyfika tego typu wyjazdów studenckich może kojarzyć się dość stereotypowo. Z promocyjnych materiałów, do jakich udało się dotrzeć autorce wynika, że wyjazdy te służą przede wszystkim dobrej zabawie, a program zapewnia rozrywki o mało ambitnej treści. Hasła promocyjne wykorzystywane $\mathrm{w}$ celu zachęcenia przyszłych studentów do uczestnictwa w obozie niosą przekaz, że jest on „niekończącą się imprezą", a „sen jest dla słabych". Warto jednak dostrzec potencjalne pole oddziaływań wychowawczych w tego typu wyjazdach turystycznych. Proponowane programy eksponują konieczność wypoczynku, w związku $\mathrm{z}$ tym można dostrzec $\mathrm{w}$ nich działania skierowane na rozwój fizyczny, podreperowanie zdrowia, niekiedy także zachęcają do aktywności fizycznej. Zdecydowanie mocniejszy nacisk jest położony na rozwój psychospołeczny. Studenci mają się przede wszyst- 
kim poznać, spędzić razem ciekawie czas, dzięki czemu można mówić o realizacji potrzeby osobistego kontaktu, lepszego zrozumienia stosunków międzyludzkich. W ramach tego typu wyjazdów jednak dosyć słabo rozwijana jest potrzeba poznawcza okolic obozu. Teren, na którym on się odbywa stanowi jedynie tło wydarzeń - jego potencjał jest bardzo mało wykorzystywany, a zapoznawanie się z okolicznymi atrakcjami realizowane jest na niskim poziomie. $Z$ drugiej jednak strony wyjazdy tego typu mogą stanowić świetną okazję do rozwijania potrzeby wolności. Oto młodzi absolwenci szkó1 średnich wkraczają na ścieżkę dorosłego życia, mogą decydować, w jaki sposób spędzą swój czas wolny, z dala od obowiązków domowych, czy szkolnych.

Podobnie może okazać się z potrzebą zaspokajania nowości. Być może to pierwsza okazja dla niektórych uczestników do przeżycia niestosowanych dotąd form spędzania wolnego czasu, pozyskiwanie nowych znajomych. W związku z tym pozytywnymi skutkami takich form wyjazdów turystycznych może być głównie kształtowanie postaw otwartości na nowe doświadczenia, na ludzi oraz wzmacnianie życzliwości i budowanie sympatii, ale najmocniej jednak skutkują realizacją założonego przez organizatorów celu - integracją studentów. W małym stopniu wpływają na poprawę zdrowia, wzmocnienie sił fizycznych, w niewielkim stopniu jest także realizowany cel poznawczy wobec odwiedzanego regionu. Zatem można przypuszczać, że obozy tego typu mogą nieść efekty w postaci dysfunkcji wychowawczych. Program wyjazdu zazwyczaj zakłada dość powierzchowne zwiedzanie, co może skutkować niechęcią do poznawania własnej kultury. Rodzaje aktywności obozowej polegają przede wszystkim na rozrywce, czego konsekwencją mogą być np. nadużywanie alkoholu, swoboda seksualna, a $\mathrm{w}$ gorszym przypadku działania niezgodne z normami współżycia społecznego. Zaplanowanie zajęć niewymagających nazbyt aktywnej postawy może w pewnym stopniu powodować pogłębianie się skłonności do biernego wypoczynku wśród młodych ludzi.

\subsection{Obozy młodzieżowe organizacji wychowawczych}

Trzecia grupa wyjazdów turystycznych organizowanych przez stowarzyszenia młodzieżowe to obozy prowadzone przez organizacje wychowawcze. Największe z nich to ZHP i ZHR. 
Plany pracy harcerskich obozów ZHP są bardzo łatwo dostępne w Internecie. Na tej podstawie oraz wykorzystując własne kontakty z członkami tej organizacji udało się podsumować najważniejsze aspekty takiego wyjazdu².

Jako przykład posłużył plan kolonii zuchowej trzech gromad z Hufca ZHP Łódź-Polesie3. Kolonia odbyła się w dniach 6-21.07.2014 roku w Podlesicach koło Kroczyc - bazie harcerskiej położonej w województwie śląskim, na terenie wyżyny Krakowsko-Częstochowskiej. W planie zawarto informacje o potencjale turystycznym miejsca - możliwości wędrówek, jazdy na rowerze, wspinaczki, zwiedzania (np. Ojcowskiego Parku Narodowego). $\mathrm{W}$ pobliskim otoczeniu znajduje się także zalew w Kostkowicach i basen w Ośrodku Wypoczynkowym w Morsku.

W dalszej części programu zaprezentowano kadrę podobozu, jej kwalifikacje, doświadczenia oraz zainteresowania, a następnie określono podział obowiązków między nimi w trakcie wyjazdu. Kolejna część zawiera szczegółowy opis każdej z trzech gromad z podziałem na chłopców i dziewczęta. $\mathrm{Na}$ tej podstawie określono cele do zrealizowania w trakcie kolonii: zdyscyplinowanie uczestników kolonii, w tym rozwijanie sprawności fizycznej, samodzielności oraz kreatywności zuchów, poszerzenie ich zainteresowań, rozwój programowy kadry. Podano także sposoby ich realizacji, np.: poranna gimnastyka, udział $\mathrm{w}$ olimpiadzie, zajęcia linowe oraz terenowe, realizacja sprawności „łazika”, praca ze zwiadem zuchowym, realizacja Odznaki Turystyki Pieszej "Siedmiomilowe Buty”.

Obozy harcerskie i kolonie zuchowe organizowane są najczęściej w oparciu o fabułę, która ma wzmacniać siłę oddziaływania wychowawczego oraz uatrakcyjniać proponowane zajęcia poprzez ich rozwijającą formę. Analizowany program zakłada tematykę „Wioski słowiańskiej”. Określono także, w jaki sposób kadra wykorzysta elementy fabuły do pracy z dziećmi. Zuchy, podzielone na mniejsze grupy (tzw. szóstki), miały zorganizowane współzawodnictwo, w którym oceniane były: porządki, realizacja sprawności, wygląd mundurów, punktualność, posiadanie proporczyka. Każda szóstka opracowywała własny proporczyk, totem, nazwę oraz okrzyk. Podczas kolonii przewidziano także przygotowanie strojów i nadawanie zuchom imion słowiańskich. Kolejnym punktem w planie jest ramowy rozkład dnia, a następnie szczegółowy grafik zajęć. W nim znajdują się takie propozycje aktywności dla uczestników, jak: tworzenie

${ }^{2}$ Autorka od 2006 r. jest instruktorem-wychowawcą w ZHP.

${ }^{3}$ Do gromad zuchowych należą dzieci z klas 1-3 szkoły podstawowej. 
obrzędowości kolonii, sadzenie roślin, zwiad, ogniska, prace pożyteczne, gry terenowe $\mathrm{z}$ elementami przyrodoznawstwa i terenoznawstwa, gry wieczorne, oglądanie filmu, zabawy tematyczne, majsterka zuchowa - rękodzieło, wędrówki i wycieczki (w tym autokarowa po Jurze Krakowsko-Częstochowskiej), kąpiel, kuchnie polowe, zajęcia kucharskie, zajęcia sprawnościowe, wspinaczka, festiwal, olimpiada.

Drugim przypadkiem jest obóz organizowany przez ZHR. Organizacja ta okazała się jedyną, która nawiązała współpracę z autorką w celu stworzenia rzetelnego opisu wychowawczej roli turystyki w swojej organizacji ${ }^{4}$. Jako przykład autorka otrzymała program obozu 6. Krakowskiej Drużyny Harcerek "Źródło", który odbył się we wsi Gwda Wielka koło Szczecinka nad Jeziorem Dołgie w dniach 6-31.07.2014 roku. W obozie uczestniczyło 21 dziewczynek $^{5}$ oraz doświadczona i wykwalifikowana kadra. Plan takiego obozu zawiera szczegółowy opis członków poszczególnych grup w ramach drużyny - zastępów, na postawie którego formułowane są założenia wychowawcze, metody pracy wraz $\mathrm{z}$ uwzględnionymi narzędziami wychowawczymi w postaci stopni i sprawności harcerskich. $W$ tym programie założono jako cele pracę nad asertywnością, potrzebą samodoskonalenia, wiarą w siebie oraz w swoje możliwości i pokorą. Warto podkreślić, że określono też cel wychowawczy dla kadry, którym było zwiększenie poczucia odpowiedzialności za zobowiązania, oraz określono zakresy odpowiedzialności poszczególnych jej członków. W analizowanym programie harcerki zaplanowały fabułę opartą na książce założyciela skautingu Roberta Baden-Powella Skauting dla chłopców oraz na działaniach opartych na idei wychowania na łonie natury i współpracowania z nią, czyli na "puszczaństwie”. Ponadto należy dodać, że jednym z elementów współzawodnictwa zastępów była realizacja programu turystycznego „Na szlaku”, poprzez takie działania, jak: INO (impreza na orientację), wędrówki (zwiad Quest w Szczecinku, wycieczka 2-4 dniowa, zwiedzanie szlaku dydaktycznego, zwiedzenie wybranego obiektu turystycznego, warsztat $\mathrm{z}$ umiejętności tradycyjnych), Zlot "Jutro Powstanie", wyjście uczestników na tzw. chatki - budowanie szałasów, odwiedzenie drużyny z innej miejscowości, stworzenie karty do kroniki, realizowanie sprawności.

${ }^{4}$ Rzeczniczka prasowa ZHR nie tylko przesłała interesujące dokumenty dotyczące wychowawczego programu organizacji, ale podała także wskazówki do odpowiedniego realizowania programu i wskazała najważniejsze wartości, do których wychowywani są członkowie tego ruchu.

${ }^{5}$ Wiek uczestniczek nie został podany, jednak z planu wynika, że przeznaczony jest dla osób $\mathrm{z}$ klasy 4-6 szkoły podstawowej oraz 1-3 gimnazjum.

160 WARSZTATY Z GEOGRAFII TURYZMU 
Dodatkowym elementem programu był zestaw zadań do wykonania przed obozem, zarówno dla całych zastępów, jak i dla ich liderów - zastępowych oraz poszczególnych członków kadry i wybranych uczestników. Plan zawierał także szczegółowy rozkład zajęć $\mathrm{w}$ ciągu dnia; ciekawym pomysłem był w nim „Kwadrans dla natury” w ramach odpoczynku poobiedniego. W szczegółowym harmonogramie zajęciowym, podzielonym na bloki (przedpołudnie, popołudnie, wieczór), można znaleźć następujące tematy zajęć: techniki harcerskie (pionierka, samarytanka, przyrodoznawstwo, terenoznawstwo, historia, łączność $)$, rozwijanie fabuły, ogniska, gry nocne, terenowe, kulinaria, śpiewogranie, zajęcia z leśniczym, wycieczki, zajęcia survivalowe, festiwal, „Chatki”, bieg na orientację, wędrówki.

Tak opracowane programy organizacji harcerskich prezentują szeroki wymiar oddziaływania wychowawczego, który może być realizowany dzięki wyjazdom turystycznym. Zaprezentowane programy kolonii i obozu obrazują sposoby i możliwości oddziaływania wychowawczego zarówno $\mathrm{w}$ aspekcie rozwoju fizycznego, jak i psychofizycznego. Bezsprzecznie można w nich znaleźć elementy, które wpływają na realizowanie potrzeby poznawczej, wolności, nowości, a także twórczości. Przemyślany program wychowawczy organizacji znajduje odzwierciedlenie $w$ realizowanych formach wyjazdów turystycznych. Dzięki nim uczestnicy mają szansę poznać zupełnie nowe otoczenie, wręcz je "poczuć", obcując z przyrodą całą dobę, nocując $w$ lesie pod namiotem. Organizatorzy z wyprzedzeniem planują, na jakie postawy i w jaki sposób chcą wpływać. Nawiązują do postaw wymienianych przez K. PRZECŁAWSKIEGO (1996): otwartość, życzliwość, sympatia, integracja, postawa patriotyczna, mierzenie się z wyzwaniami. Warto także podkreślić wykorzystywany potencjał możliwości kształtowania uczuć, np. zachwytu nad pięknem i kontemplacji natury poprzez bliskie z nią obcowanie. Zajęcia proponowane $\mathrm{w}$ obu przypadkach pozwalają także odkrywać i rozwijać potencjał twórczy, dają szansę dbania o poprawę zdrowia i kondycji fizycznej. Przy opisanych tak szczegółowo założeniach oraz zaplanowanych zajęciach niezwykle trudno jest przewidzieć dysfunkcje tego typu wyjazdów. Jedynie niespełnienie zaplanowanych celów, nieumiejętna praca wychowawców, organizatorów, czy też niewłaściwa postawa uczestników mogą zaważyć o negatywnych skutkach tego rodzaju wyjazdów turystycznych.

${ }^{6}$ Techniki harcerskie stanowią podstawową wiedzę harcerzy z wymienionych dziedzin. 


\section{Podsumowanie}

Wychowanie to proces bardzo złożony. Niezwykle trudno jest jednoznacznie i bez wątpliwości ocenić, jakie będą skutki oddziaływania wychowawczego podczas zaplanowanego wyjazdu turystycznego. Co niezaprzeczalne, to bogactwo możliwości i szans, jakie daje turystyka świadomym i odpowiedzialnym wychowawcom. Rozwój popularności wyjazdów turystycznych oraz organizowania wypoczynku dla dzieci i młodzieży powinien przynieść głęboką refleksję nad tym zagadnieniem. Powszechność tego typu działań widać chociażby w częstości zapisów statutowych analizowanych organizacji odnoszących się do turystyki. Większość z nich uznawała ją jako swój cel bądź środek do jego realizacji. Często wymienianym celem analizowanych stowarzyszeń i organizacji młodzieżowych jest propagowanie turystyki i aktywnego wypoczynku. Do realizacji wyznaczanych celów często także wykorzystują one różnorodne formy wyjazdów turystycznych - w tym obozów czy wymian młodzieżowych i studenckich.

Przedstawione studia przypadków obrazują zarówno szanse, jak i zagrożenia wychowawcze, jakie mogą nieść ze sobą obozy młodzieżowe. Obozy sportowe organizowane przez AZS na pewno przyczyniają się do popularyzacji turystyki oraz dzięki niej wpływają na rozwój fizyczny uczestników. Według statutu tej organizacji jej celem jest upowszechnianie kultury fizycznej i turystyki poprzez organizację różnych form aktywności sportowej, rekreacyjnej i turystycznej. Turystyka w przypadku organizacji i stowarzyszeń młodzieżowych jest zarówno celem, jak i środkiem do osiągania celów. Ma to potwierdzenie w zaprezentowanym przykładzie. Podobnie dowodzi temu przykład obozów integracyjnych organizowanych przez ZSP i ESN. Organizacje AIESEC, ZHP i ZHR w swoich statutach również podkreślają, że turystyka jest dla nich środkiem do osiągnięcia celów. Szczególnie mocno warto podkreślić siłę oddziaływania wychowawczego prezentowanego przez organizacje harcerskie. Przemyślane, szeroko zakrojone cele odwołujące się do realnych potrzeb uczestników mają szansę na pozytywną realizację dzięki bogatemu, różnorodnemu programowi nastawionemu na indywidualny oraz grupowy rozwój. Dodatkowym atutem jest także wysoka świadomość wychowawców - organizatorów wyjazdu, którzy również sobie stawiają wyzwania. Dzięki temu siła oddziaływania wychowawczego może być jeszcze mocniejsza.

Ten aspekt autorka uważa za klucz do sukcesu. Forma wyjazdu, rodzaj odwiedzanego miejsca, warunki wyjazdu i jego organizacja pomagają oraz 
ułatwiają działania wychowawcze, ale za tego typu decyzjami zawsze stoi „ktoś" - organizator wypoczynku. To przede wszystkim jego postawa, profesjonalizm i świadomość wychowawczej roli turystyki pozwala na realne i owocne kształtowanie osobowości uczestników wyjazdu - człowieka w turystyce.

\section{Bibliografia}

BABBIE E., 2003, Badania spoteczne w praktyce, Wyd. Naukowe PWN, Warszawa.

BALIŃSKA A., SIECZKO A., ZAWADKA J., 2014, Turystyka. Wybrane zagadnienia, Wyd. Difin, Warszawa.

BOCHENEK M., 2008, Turystyka w edukacji dzieci i młodzieży, Akademia Wychowania Fizycznego Józefa Piłsudskiego w Warszawie, Zamiejscowy Wydział Wychowania Fizycznego, Biała Podlaska.

DĄBROWSKI A., PODLEŚNA-DUDICZ K., 2009, Kilka uwag w sprawie wartości wychowawczych turystyki i rekreacji ruchowej, [w:] A. Dąbrowski, R. Rowiński (red.), Wychowawcze wartości turystyki i rekreacji, Akademia Wychowania Fizycznego Józefa Piłsudskiego, Warszawa.

GAWORECKI W. W., 2010, Turystyka, Polskie Wyd. Ekonomiczne, Warszawa.

KUREK W. (red.), 2008, Turystyka, Wyd. Naukowe PWN, Warszawa.

KWIECIŃSKI Z., ŚLIWERSKI B., 2011, Pedagogika. Podręcznik akademicki, t. 1, Wyd. Naukowe PWN, Warszawa.

PANASIUK A. red., 2011, Ekonomika turystyki i rekreacji, Wyd. Naukowe PWN, Warszawa.

PRZECŁAWSKI K., 1973, Turystyka a wychowanie, Nasza Księgarnia, Warszawa.

PRZECŁAWSKI K., 1996, Cztowiek a turystyka. Zarys socjologii turystyki, Kraków.

WINIARSKI R. (red.), 2008, Turystyka w naukach humanistycznych, Wyd. Naukowe PWN, Warszawa. http://aiesec.pl/; 24.02.2016.

http://aiyd.eu/zerowka/atrakcje/; 3.03.2016.

http://azs.pl/images/dokumenty/akty-prawne/statut2014.pdf; 11.02.2016.

http://centrumwolontariatu.eu/o-nas/statut/; 11.02.2016.

http:// docplayer.pl/5615463-Statut-stowarzyszenia-all-ternatywa-stowarzyszenie-jeleniogorskiejmlodziezy-z-dnia-2012-08-05-rozdzial-i-postanowienia-ogolne.html; 22.02.2016.

http://dokumenty.zhp.pl/1_strona_glowna-i._statut,_decyzje_zjazdowe; 24.02.2016.

http://esn.pl/sites/default/files/pages/statut_stowarzyszenia_esn_polska_z_dn._30.06.2012__poprawki_sd_poronin_-_tekst_jedn._14.03.2015_0.pdf; 11.02.2016.

http://jes.org.pl/o-nas/; 15.02.2016.

http://jes.org.pl/statut/; 15.02.2016.

http://pej.pl/o-nas/dokumenty/statut-polskiego-zwiazku-esperantystow/?lang=pl; 11.02.2016.

http://projektpolska.pl/stowarzyszenie/statut-stowarzyszenia/; 12.02.2016.

http://projekttarnow.org/docs/Statut.pdf; 15.02.2016.

http://prom.info.pl/o-nas/dokumenty/; 15.02.2016.

http://spektrummozliwosci.pl/informacje/; 24.02.2016.

http://www.bjdm.eu/onas; 12.02.2016.

http:// www.cimhoryzonty.org/statut-organizacji,14; 12.02 .2016$.

http://www.eyca.pl/pl/o_karcie/o_nas/statut_pspm/; 11.02.2016.

http://www.kuazsuw.pl/obozy; 3.03.2016.

http://www.smd.org.pl/wp-content/uploads/2010/09/statut_stowarzyszenia_mlodzi_demokraci_ tekst_jednolity_2012.pdf; 11.02.2016.

http://www.volleycamp.pl/; 3.03.2016. 
http://www.volleycamp.pl/opinie/; 3.03.2016.

http://www.zerujemyrazem.pl/index.html; 3.03.2016.

http://www.zhr.pl/wp-content/uploads/2014/08/statut_ZHR_kwiecien_2014.pdf; 11.02.2016.

http://www.zmw.pl/data_files/wysiwyg/Statut\%20ZMW.pdf; 11.02.2016.

http://zsp.pl/strony/o-nas/; 23.02.2016.

https://drive.google.com/file/d/0B-jhrqu39QwCUFpMTjEwOXIILTA/view; 24.02.2016.

https://www.facebook.com/events/583412575133649/; 2.03.2.016. 